\title{
Effect of Different Plant Growth Regulators on Growth, Yield and Quality Parameters in Cucumber (Cucumis sativus L.) under Polyhouse Condition
}

\author{
Ajay S. Kadi", K.P. Asati, Swati Barche and R.G. Tulasigeri \\ College of Agriculture, Indore, Madhya Pradesh, India \\ *Corresponding author
}

\begin{tabular}{|c|}
\hline Keywords \\
\hline $\begin{array}{l}\text { Growth regulators, } \\
\text { GA }_{3} \text {, NAA, } \\
\text { Growth, Cucumber }\end{array}$ \\
\hline Article Info \\
\hline $\begin{array}{l}\text { Accepted: } \\
26 \text { March } 2018 \\
\text { Available Online: } \\
10 \text { April } 2018\end{array}$ \\
\hline
\end{tabular}

An experiment was conducted during 2016-17 at College of Agriculture, Indore to study the effect of Different Plant Growth Regulators on Growth, Yield and Quality Parameters in Cucumber (Cucumis sativus L.) under Polyhouse Condition. The treatment with $\mathrm{GA}_{3}$ $100 \mathrm{ppm}$ has recorded the maximum in Growth parameters viz., vine length $(139.89 \mathrm{~cm})$, number of leaves (59.46), number of branches (17.00), leaf area $(293.28 \mathrm{~cm})$ and whereas internodal distance has recorded the maximum in the treatment of NAA (50 ppm) and phenological parameters viz., average days taken to first flowering, days taken to $50 \%$ flowering and days taken to first picking was recorded in the treatment $\mathrm{GA}_{3} 200 \mathrm{ppm}$ (valued 34.46, 37.01 and 52.55, respectively) and sex ratio was maximum in the treatment NAA $100 \mathrm{ppm}$ (valued 2.20:1). The maximum fruit set percentage and fruit retention percentage was maximum in treatment $\mathrm{GA}_{3}$ 200ppm (valued 82.90 and 84.84 , respectively). While other parameters like length of fruits, diameter of fruits, number of fruits per plant and fruit yield $\left(\mathrm{q} / \mathrm{ha}\right.$ ) were maximum in the treatment $\mathrm{GA}_{3} 100 \mathrm{ppm}$ (valued 22.36, 4.6, 9.24 and 178.67, respectively). Quality parameters like TSS maximum was recorded in the treatment $\mathrm{GA}_{3} 200 \mathrm{ppm}$ (valued 6.06).

\section{Introduction}

Cucumber (Cucumis sativus L.) is a widely cultivated plant, belonging to the family Cucurbitaceae and having a chromosome number, $2 \mathrm{n}=14$. It is an endemic vegetable of India (De Candole, 1967). Cucumber is commonly a monoecious, annual, trailing or climbing vine (Bailey, 1969) having hirsute or scabrous stems with triangular ovate leaves with shallow and acute sinuses. Cucumber exhibits a fascinating range of floral morphology, including staminate, pistillate and hermaphrodite flowers occurring in various arrangements and yielding several types of sexual expression.

Growth regulators have tremendous effects on sex expression and flowering in various cucurbits leading to either suppression of male flowers or an increase in the number of female flowers (Masoum and Masri, 1999) without imposing any deleterious effect on the environment and human health. Exogenous application of plant growth regulators can alter the sex ratio and sequence if applied at the two- or four-leaf stage, which is the critical stage at which the suppression or promotion of 
either sex is possible (Hossain et al., 2006). The effects of plant growth regulators in cucumber exhibits a fascinating range of floral morphology, including staminate, pistillate and hermaphrodite flowers occurring in various arrangements and yielding several types of sexual expression. Furthermore, these types are affected greatly by environmental factors as well as hormones in the plant system. Plant growth regulators are also used to control the vegetative growth of cucumber plants, thereby increasing the plant population per unit area with regard to yield (Latimer, 1991).

\section{Materials and Methods}

The experimental trials "Effect of Different Plant Growth Regulators on Growth, Yield and Quality Parameters in Cucumber (Cucumis sativus L.) under Polyhouse Condition" was conducted at the polyhouse, Department of Horticulture, College of Agriculture Indore (M.P.) during the year 2016-2017. This experiment was carried out to see the effect of foliar application of different growth regulators on growth, yield and quality parameters in cucumber under polyhouse condition.

The experiment was laid out in Randomized Block Design (RBD) with three replications. The experiment comprised of nine with the combinations of plant growth regulators, namely Gibberellic acid $\left(\mathrm{GA}_{3}\right)$, Naphthalene acetic acid (NAA) and Ethrel these used at different concentrations. Ridge and furrow method was applied for sowing of seed. Two seeds per hill was sown in the month of September under poly house condition.

Sowing was done in the month of September on two seeds per hill on ridges were sown at a depth of 2-3 cm. Later, gap filling and thinning were done to retain one plant per hill. A regular watering and plant protection measures were carried out as and when required. Well rotten Farm Yard Manure was applied @20 tons/ha before preparing of the bed. Nitrogen, Phosphorus and potash were applied @ 90:50:40 kg/ha in the form of urea, single super phosphate and murate of potash, respectively.

The plants were trained upward so that the main stem was allowed to climb to the overhead wire along a rope. Wires were fixed 8-9 feet above the ground. The twine of each plant was alternatively tied to the horizontal overhead wires running along with the length of rows. The base of the twine (string) was anchored loosely to the base of the stem with a non-slip vine. As the stem developed, it was trellised on the twine up to the height of horizontal wires (8-9 feet height) and then the vines were again turned downward direction.

First hoeing and weeding was done after twenty days of sowing. Crop was protected from the attack of insect and pests like aphids, whiteflies and thrips, Imidacloprid $(0.04 \%)$ was sprayed at twenty five days interval as a precautionary measure after sowing. Besides, to protect the crop from fungal disease as Fusarium root rot, fungicide Mancozeb @ 2.0 $\mathrm{g} /$ litre of water was sprayed at fifteen days interval during the entire experimental period.

Light irrigation was applied for establishment of seed. The irrigation at weekly interval was given as and when required and after one month the irrigation interval was increased to ten days.

\section{Growth parameters}

\section{Seed germination per cent}

The emergence of plumule and radical were taken as index of germination. Initiation and completion of germination were recorded daily for eight days and germination 
percentage was calculated using the following formula.

No. of seedlings emerged

Germination percentage = --------------- X 100

No. of seeds sown

\section{Vine length}

Vine length of five randomly selected plants were measured with the help of meters scale from the base of the vine to its tip and average length of vine was calculated and expressed in centimetres.

Observations were taken at 15, 30, 45 and 60 days respectively after sowing. It least five plants should have been selected randomly.

\section{Number of leaves per plant}

The total number of leaves in five randomly selected plants was counted periodically until the final harvesting of plant from each plot and average number of leaves per vine was calculated.

Observations were taken at 15, 30, 45 and 60 days after sowing.

\section{Number of branches per plant}

The total numbers of branches in five randomly selected plants were counted periodically until the final harvesting completed from each plot and average number of branches per vine was calculated.

Observations were taken at 15, 30, 45 and 60 days after sowing.

\section{Inter-nodal distance $(\mathrm{cm})$}

The distance between the nodes of five plants was measured from the middle of the vine using a scale and the average was calculated.

\section{Leaf area $\left(\mathrm{cm}^{2}\right)$}

The leaf area of five leaves was measured on leaf-area-meter (manufactured by Systronics Ltd.).

And average leaf area of a single leaf was worked out and expressed in $\mathrm{cm}^{2}$. Observations were taken at 15, 30, 45 and 60 days after sowing.

\section{Phenological parameters}

\section{Days taken to first flowering}

The date of first flower bud initiation was recorded in each treatment and the numbers of days were counted from the date of sowing.

\section{Days taken to $50 \%$ flowering}

The total number of days taken for $50 \%$ of the plants to bear flowers in each treatment plot from the date of sowing was counted and the average was calculated.

\section{Days to fruit maturity}

The number of days required to harvest the first marketable fruit when they attain a tender and horticultural maturity from the date of sowing was recorded.

\section{Male and female ratio}

The sex ratio was recorded as the ratio of staminate to pistillate flowers at the flowering stage, counted from the appearance of the first flower until the last flower on each tagged plant.

\section{Fruit set percentage}

The data of fruit set percentage was recorded in each treatment and its average was calculated. 


\section{Fruit retention percentage}

The fruit retention percentage were recorded by usual observation in each treatments and its average was calculated.

\section{Yield parameters}

\section{Number of fruits per plant}

The number of fresh marketable fruits harvested from five randomly selected plants was recorded.

At each harvesting and average number of fruits per vine (plant) was calculated.

\section{Length of fruits $(\mathrm{cm})$}

The length of five randomly selected fruits at marketable stage was measured from head end up to blossom scar by meter scale.

In each treatment then the average fruit length was calculated and expressed in centimeters.

\section{Diameter of the fruits $(\mathrm{cm})$}

Fruit diameter was taken at five different places i.e., stalk end, middle end and floral end with the help of Vernier callipers and average diameter was calculated.

\section{Fruit yield (q/ha)}

The fruit yield per hectare was calculated by multiplying the fruit yield per plant by the total number of plants on one hectare.

\section{Quality parameters}

\section{Total soluble solid (TSS \%)}

Total soluble solid percentage was determined with the help of hand refractometer at the time of harvesting of fruits.

\section{Physiological loss in weight (PLW \%)}

For determining Physiological loss in weight of cucumber at alternate days, the weight of the cucumber fruits was recorded and the total loss of physiological weight was then calculated by subtracting the final weight of the cucumber from the initial weight. The results were then expressed in percentage using following formula:

$$
\% \mathrm{PLW}=\frac{\text { Initial weight }- \text { Final weight }}{\text { Initial weight }}
$$

\section{Texture of fruit}

Texture of fruit was recorded by visual observation and categorized into following categories.

Smooth

Rough

\section{Results and Discussion}

The data on various observations recorded during experimentation were subjected to statistical analysis in Randomized Block Design in order to find out the significance of different treatments by using the analysis of variance. The results have been integrated along with the corresponding tables and figures.

It is clear from the table 1 and depicted in Figure 1 that the maximum vine length (valued $139.89 \mathrm{~cm}$ ) in treatment $\mathrm{T}_{1}-\mathrm{GA}_{3}$ @ 100ppm and while minimum was recorded in treatment $\mathrm{T}_{9}$-control (valued $127.14 \mathrm{~cm}$ ). The promotion of growth either in terms of increase in the vine length or the leaf area and leaf number has been thought to be by increasing plasticity of the cell wall followed by hydrolysis of starch to sugars which lowers the water potential of cell, resulting in the 
entry of water into the cell causing elongation. These osmotic driven responses under the influence of gibberellins might have attributed to increase in photosynthetic activity, accelerated translocation and efficiency of utilizing photosynthetic products, thus resulting in increased cell elongation and rapid cell division in the growing portion (Sargent, 1965).

In general the number of leaves, number of branches and leaf area were maximum in the treatment $\mathrm{T}_{1}-\mathrm{GA}_{3} @ 100 \mathrm{ppm}$ (valued 59.46, 17.00 and $293.28 \mathrm{~cm}^{2}$, respectively) and while minimum was recorded in the treatment $\mathrm{T}_{9^{-}}$ control (valued 45.89, 8.69 and 258.92, respectively). The Inter-nodal distance was showed in the table 1 and depicted Figure 1. Maximum inter-nodal distance was recorded in the treatment $\mathrm{T}_{4}$ - NAA @50 ppm valued (valued $8.33 \mathrm{~cm}$ ) and minimum was recorded in treatment $\mathrm{T}_{9}$-control (valued $4.70 \mathrm{~cm}$ ). Increase in the number of leaves might be due to its additional availability of GA in seed, which might have increased the level of amylase in the aleurone tissues of seed for better conversion of complex starch into simple sugars for providing energy to growth (Ram Asrey et al., 2001).

It has been observed in the present study that the application of plant growth regulators had profound influence on assimilatory surface area and its associated characters. This could be attributed to the stimulatory effect of the plant growth regulators on cell division and cell enlargement, which lead to enhanced leaf area and hence influenced the growth and development (Geeta et al., 2010).

\section{Phenological parameters}

It is clear from the Table 2 and depicted in the Figure 2 in that the average days taken to first flowering, days taken to $50 \%$ flowering and days taken to first picking was recorded in the treatment $\mathrm{T}_{2}-\mathrm{GA}_{3} @ 200$ ppm (valued 34.46, 37.01 and 52.55, respectively) and while maximum was recorded in the treatment $\mathrm{T}_{9^{-}}$ Control (valued 44.78, 43.07 and 59.51, respectively).

From table 2 showed that sex ratio was maximum in the treatment $\mathrm{T}_{5} @ 100$ ppm (valued 2.20:1) and while minimum was recorded in the treatment $\mathrm{T}_{9^{-}}$Control (valued 1.37:1). Gedam et al., (1998) conducted an experiment in 1992 where bitter gourd plants were sprayed at 40, 55, 70, 80 and 100 days after sowing with $\mathrm{GA}_{3}$ at 15,25 and $35 \mathrm{ppm}$, NAA at 50, 100 and $150 \mathrm{ppm}$, ethephon at 50, 100 , and $150 \mathrm{ppm}, \mathrm{MH}$ at 100, 200, and 300 ppm and boron at 2, 4 and 6 ppm with water (control). $\mathrm{GA}_{3}$ at $35 \mathrm{ppm}$ produced the earliest female flower and NAA at $50 \mathrm{ppm}$ produced the earliest male flower.

\section{Yield and its attributing traits}

The data for various treatments with respect to fruit set percentage, fruit retention percentage, length of fruits, diameter of fruits, number of fruits per plant and fruit yield $(\mathrm{q} / \mathrm{ha})$ that are summarized in Table 3 and diagrammatically exhibited in Figure 3.

The maximum fruit set percentage and fruit retention percentage was maximum in treatment $\mathrm{T}_{2}-\mathrm{GA}_{3} @ 200 \mathrm{ppm}$ (valued 82.90 and 84.84, respectively). While minimum was recorded in treatment $\mathrm{T}_{9}$-Control (valued 71.00 and 77.23 , respectively).

While other parameters like length of fruits, diameter of fruits, number of fruits per plant and fruit yield were maximum in the treatment $\mathrm{T}_{1}-\mathrm{GA}_{3} @ 100$ ppm (valued 22.36, 4.6, 9.24 and 178.67, respectively). While minimum was recorded in treatment $\mathrm{T}_{9}$-Control (valued $16.99,1.61$ and $160 \mathrm{q} /$ ha, respectively) except diameter of fruits it was recorded in treatment $\mathrm{T}_{8}$ - Ethrel @ 300 ppm (3.4) (Table 4). 


\section{Total cost of cultivation}

\begin{tabular}{|l|l|}
\hline Basic cost of cultivation & Rs. $30,000 / h a$ \\
\hline Cost of Gibberellic acid & Rs. $50 / \mathrm{g}$ \\
\hline Cost of Naphthalene acetic acid & Rs. $250 / 100 \mathrm{ml}$ \\
\hline Cost of Naphthalene acetic acid & Rs. $290 / 250 \mathrm{ml}$ \\
\hline Cost of Ethrel & Rs. $400 /$ liter. \\
\hline Market price of cucumber & Rs. $10 / \mathrm{Kg}$. \\
\hline
\end{tabular}

Table.1 Growth parameters

\begin{tabular}{|c|c|c|c|c|c|}
\hline Treatments & $\begin{array}{l}\text { Vine } \\
\text { length }\end{array}$ & $\begin{array}{l}\text { No. of } \\
\text { leaves }\end{array}$ & $\begin{array}{c}\text { No. } \\
\text { branches }\end{array}$ & $\begin{array}{l}\text { Leaf } \\
\text { area }\end{array}$ & $\begin{array}{l}\text { Internodal } \\
\text { distance }\end{array}$ \\
\hline $\mathrm{T}_{1}-\mathrm{GA}_{3}(100 \mathrm{ppm})$ & 139.89 & 59.46 & 17.00 & 293.28 & 4.87 \\
\hline $\mathrm{T}_{2}-\mathrm{GA}_{3}(200 \mathrm{ppm})$ & 133.07 & 58.41 & 15.81 & 285.29 & 5.70 \\
\hline $\mathrm{T}_{3}-\mathrm{GA}_{3}(250 \mathrm{ppm})$ & 132.95 & 57.48 & 16.33 & 279.59 & 8.00 \\
\hline $\mathrm{T}_{4}-\mathrm{NAA}(50 \mathrm{ppm})$ & 132.66 & 53.81 & 14.23 & 281.22 & 8.33 \\
\hline $\mathrm{T}_{5}-\mathrm{NAA}(100 \mathrm{ppm})$ & 128.60 & 51.32 & 13.62 & 280.89 & 7.61 \\
\hline $\mathrm{T}_{6}-\mathrm{NAA}(150 \mathrm{ppm})$ & 129.18 & 48.96 & 10.02 & 276.78 & 6.51 \\
\hline$T_{7}$ - Ethrel (200 ppm) & 131.15 & 49.28 & 9.29 & 266.33 & 5.25 \\
\hline $\mathrm{T}_{8}$ - Ethrel (300 ppm) & 131.88 & 46.95 & 9.87 & 278.96 & 6.77 \\
\hline $\begin{array}{l}\text { T}_{9} \text { - Control (Water } \\
\text { spray) }\end{array}$ & 127.14 & 45.89 & 8.69 & 258.92 & 4.70 \\
\hline S.Em \pm & 0.54 & 0.68 & 0.66 & 0.97 & 0.53 \\
\hline CD at $5 \%$ Level & 1.49 & 1.67 & 1.65 & 2.0 & 1.48 \\
\hline
\end{tabular}

Table.2 Phenological parameters

\begin{tabular}{|c|c|c|c|c|c|c|}
\hline Treatments & $\begin{array}{c}\text { Days } \\
\text { taken to } 1^{\text {st }} \\
\text { flowering }\end{array}$ & $\begin{array}{c}\text { Days } \\
\text { taken to } \\
50 \% \\
\text { flowering }\end{array}$ & $\begin{array}{c}\text { Days } \\
\text { taken to } \\
\text { picking }\end{array}$ & $\begin{array}{l}\text { No. of } \\
\text { male } \\
\text { flowers }\end{array}$ & $\begin{array}{l}\text { No. of } \\
\text { female } \\
\text { flowers }\end{array}$ & $\begin{array}{c}\text { Sex ratio } \\
(\mathrm{M} / \mathrm{F})\end{array}$ \\
\hline $\mathrm{T}_{1}-\mathrm{GA}_{3}(100 \mathrm{ppm})$ & 34.52 & 38.36 & 54.75 & 88.87 & 52.67 & $1.68: 1$ \\
\hline $\mathrm{T}_{2}-\mathrm{GA}_{3}(200 \mathrm{ppm})$ & 34.46 & 37.01 & 52.55 & 89.19 & 45.22 & $1.97: 1$ \\
\hline $\mathrm{T}_{3}-\mathrm{GA}_{3}(250 \mathrm{ppm})$ & 35.84 & 37.99 & 55.37 & 87.56 & 45.92 & 2.03:1 \\
\hline $\mathrm{T}_{4}$ - NAA (50 ppm) & 36.92 & 39.18 & 55.40 & 90.62 & 47.47 & 1.90:1 \\
\hline $\mathrm{T}_{5}-\mathrm{NAA}(100 \mathrm{ppm})$ & 36.70 & 42.11 & 56.51 & 96.58 & 43.80 & $2.20: 1$ \\
\hline $\mathrm{T}_{6}$ - NAA (150 ppm) & 40.08 & 40.52 & 56.18 & 93.41 & 46.30 & $2.01: 1$ \\
\hline $\mathrm{T}_{7}$ - Ethrel $(200 \mathrm{ppm})$ & 37.62 & 41.39 & 55.45 & 95.44 & 48.53 & 1.96:1 \\
\hline $\mathrm{T}_{8}-$ Ethrel $(300 \mathrm{ppm})$ & 40.62 & 41.20 & 57.92 & 96.41 & 37.14 & 2.59:1 \\
\hline $\begin{array}{l}\mathrm{T}_{9} \text { - Control (Water } \\
\text { spray) }\end{array}$ & 44.78 & 43.07 & 59.41 & 79.01 & 57.26 & $1.37: 1$ \\
\hline S.Em \pm & 0.99 & 0.83 & 0.87 & 0.53 & 0.45 & 0.03 \\
\hline CD at 5\% Level & 2.01 & 1.85 & 1.89 & 1.47 & 1.36 & 0.35 \\
\hline
\end{tabular}


Int.J.Curr.Microbiol.App.Sci (2018) 7(4): 3339-3352

Table.3 Yield and its attributing traits

\begin{tabular}{|c|c|c|c|c|c|c|}
\hline Treatments & $\begin{array}{c}\text { Fruit set } \\
\%\end{array}$ & $\begin{array}{c}\text { Fruit } \\
\text { retention \% }\end{array}$ & $\begin{array}{l}\text { Length } \\
\text { of fruits }\end{array}$ & $\begin{array}{l}\text { Diameter } \\
\text { of fruits }\end{array}$ & $\begin{array}{l}\text { Number of } \\
\text { fruit/ plant }\end{array}$ & $\begin{array}{l}\text { Fruit yield } \\
\text { (q/ha) }\end{array}$ \\
\hline $\mathrm{T}_{1}-\mathrm{GA}_{3}(100 \mathrm{ppm})$ & 79.60 & 82.84 & 22.36 & 4.6 & 9.24 & 178.67 \\
\hline $\mathrm{T}_{2}-\mathrm{GA}_{3}(200 \mathrm{ppm})$ & 82.90 & 84.84 & 21.85 & 4.4 & 8.01 & 172.67 \\
\hline $\mathrm{T}_{3}-\mathrm{GA}_{3}(250 \mathrm{ppm})$ & 79.20 & 82.13 & 21.08 & 4.1 & 9.16 & 178.00 \\
\hline $\mathrm{T}_{4}-\mathrm{NAA}(50 \mathrm{ppm})$ & 78.50 & 80.86 & 21.64 & 4.0 & 8.96 & 174.79 \\
\hline $\mathrm{T}_{5}-\mathrm{NAA}(100 \mathrm{ppm})$ & 73.50 & 81.03 & 21.40 & 3.7 & 8.70 & 158.30 \\
\hline $\mathrm{T}_{6}-\mathrm{NAA}(150 \mathrm{ppm})$ & 74.50 & 80.40 & 20.99 & 4.0 & 7.93 & 167.33 \\
\hline $\mathrm{T}_{7}-$ Ethrel $(200 \mathrm{ppm})$ & 73.30 & 79.14 & 17.19 & 3.0 & 8.42 & 169.07 \\
\hline $\mathrm{T}_{8}$ - Ethrel (300 ppm) & 76.00 & 79.18 & 19.55 & 3.4 & 7.73 & 169.33 \\
\hline $\begin{array}{l}\mathrm{T}_{9} \text { - Control (Water } \\
\text { spray) }\end{array}$ & 71.00 & 77.23 & 16.99 & 3.8 & 7.16 & 160.00 \\
\hline S.Em \pm & 1.59 & 0.62 & 0.54 & 0.34 & 0.45 & 1.00 \\
\hline CD at 5\% Level & 4.78 & 1.59 & 1.49 & 1.02 & 1.37 & 2.02 \\
\hline
\end{tabular}

Table.4 Quality parameters

\begin{tabular}{|c|c|c|}
\hline Treatments & $\begin{array}{c}\text { Total soluble } \\
\text { solids }\end{array}$ & Texture of fruits \\
\hline $\mathrm{T}_{1}-\mathrm{GA}_{3}(100 \mathrm{ppm})$ & 3.61 & Rough \\
\hline $\mathrm{T}_{2}-\mathrm{GA}_{3}(200 \mathrm{ppm})$ & 6.06 & Rough \\
\hline $\mathrm{T}_{3}-\mathrm{GA}_{3}(250 \mathrm{ppm})$ & 4.40 & Rough \\
\hline $\mathrm{T}_{4}-\mathrm{NAA}(50 \mathrm{ppm})$ & 2.96 & Rough \\
\hline $\mathrm{T}_{5}-\mathrm{NAA}(100 \mathrm{ppm})$ & 3.85 & Rough \\
\hline $\mathrm{T}_{6}$ - NAA (150 ppm) & 3.92 & Rough \\
\hline $\mathrm{T}_{7}-$ Ethrel $(200 \mathrm{ppm})$ & 2.16 & Smooth \\
\hline $\mathrm{T}_{8}-$ Ethrel (300 ppm) & 3.31 & Smooth \\
\hline $\mathrm{T}_{9}$ - Control (Water spray) & 4.11 & Rough \\
\hline S.Em \pm & 0.59 & - \\
\hline CD at 5\% Level & 1.56 & - \\
\hline
\end{tabular}


Table.5 Cost: Benefit ratio of different cucumber treatment

\begin{tabular}{|c|c|c|c|c|c|c|}
\hline Treatments & $\begin{array}{l}\text { Yield } \\
\text { (q/ha) }\end{array}$ & $\begin{array}{l}\text { Gross } \\
\text { returns } \\
\text { (Rs/ha) }\end{array}$ & $\begin{array}{l}\text { Cost of } \\
\text { treatments } \\
\text { (Rs/ha) }\end{array}$ & $\begin{array}{l}\text { Total cost of } \\
\text { cultivation } \\
\text { (Rs/ha) }\end{array}$ & $\begin{array}{c}\text { Net returns } \\
\text { (Rs/ha) }\end{array}$ & C:B ratio \\
\hline $\mathrm{T}_{1}-\mathrm{GA}_{3}(100 \mathrm{ppm})$ & 178.67 & 85500 & 1750 & 44075 & 41425 & $1: 2.6$ \\
\hline $\mathrm{T}_{3}-\mathbf{G A 3}(250 \mathrm{ppm})$ & 178.00 & 82500 & 450 & 43275 & 39225 & $1: 2.6$ \\
\hline $\mathbf{T}_{4}-\mathbf{N A A}(50 \mathrm{ppm})$ & 174.79 & 84000 & 920 & 43900 & 40100 & $1: 2.7$ \\
\hline $\mathbf{T}_{5}-\mathbf{N A A}(100 \mathrm{ppm})$ & 158.30 & 84500 & 2120 & 45250 & 40625 & $1: 2.6$ \\
\hline $\mathrm{T}_{6}-\mathrm{NAA}(150 \mathrm{ppm})$ & 167.33 & 85000 & 3670 & 43200 & 39750 & $1: 2.5$ \\
\hline $\mathrm{T}_{7^{-}}$Ethrel(200ppm) & 169.07 & 81000 & 175 & 42500 & 37800 & $1: 2.6$ \\
\hline T8- Etherl(300 ppm) & 169.33 & 80500 & 370 & 39950 & 38000 & $1: 2.6$ \\
\hline T9-Control & 160.00 & 66560 & - & 39950 & 26610 & $1: 1.7$ \\
\hline
\end{tabular}


Fig.1 Performance of different treatments of cucumber for vine length, number of leaves per plant, number of branches per plant, leaf area and internodal distance under polyhouse condition

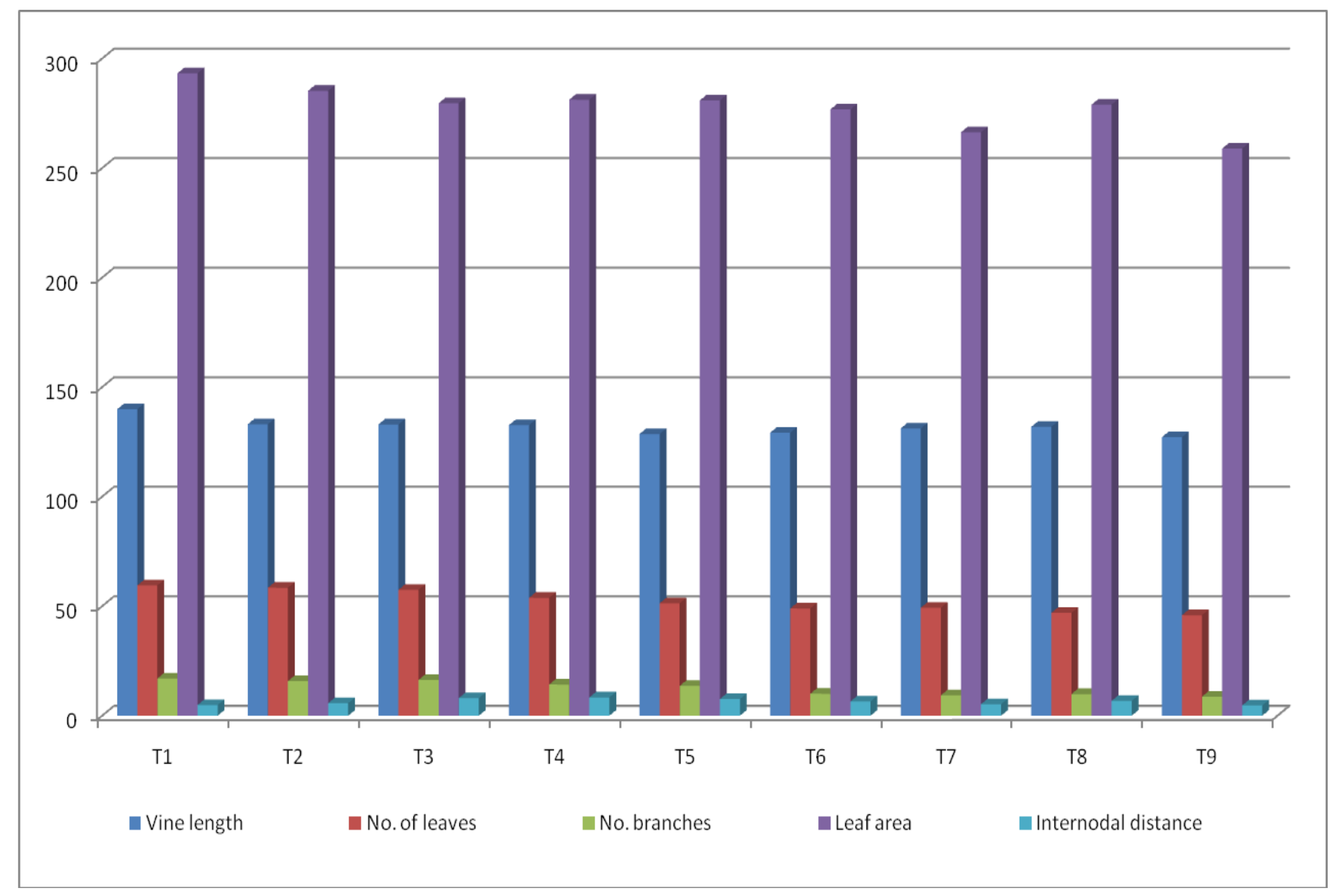


Fig.2 Days taken to first flowering, days taken to 50\% flowering, first picking, number of male flowers and number of female flowers of different treatments of cucumber under polyhouse condition

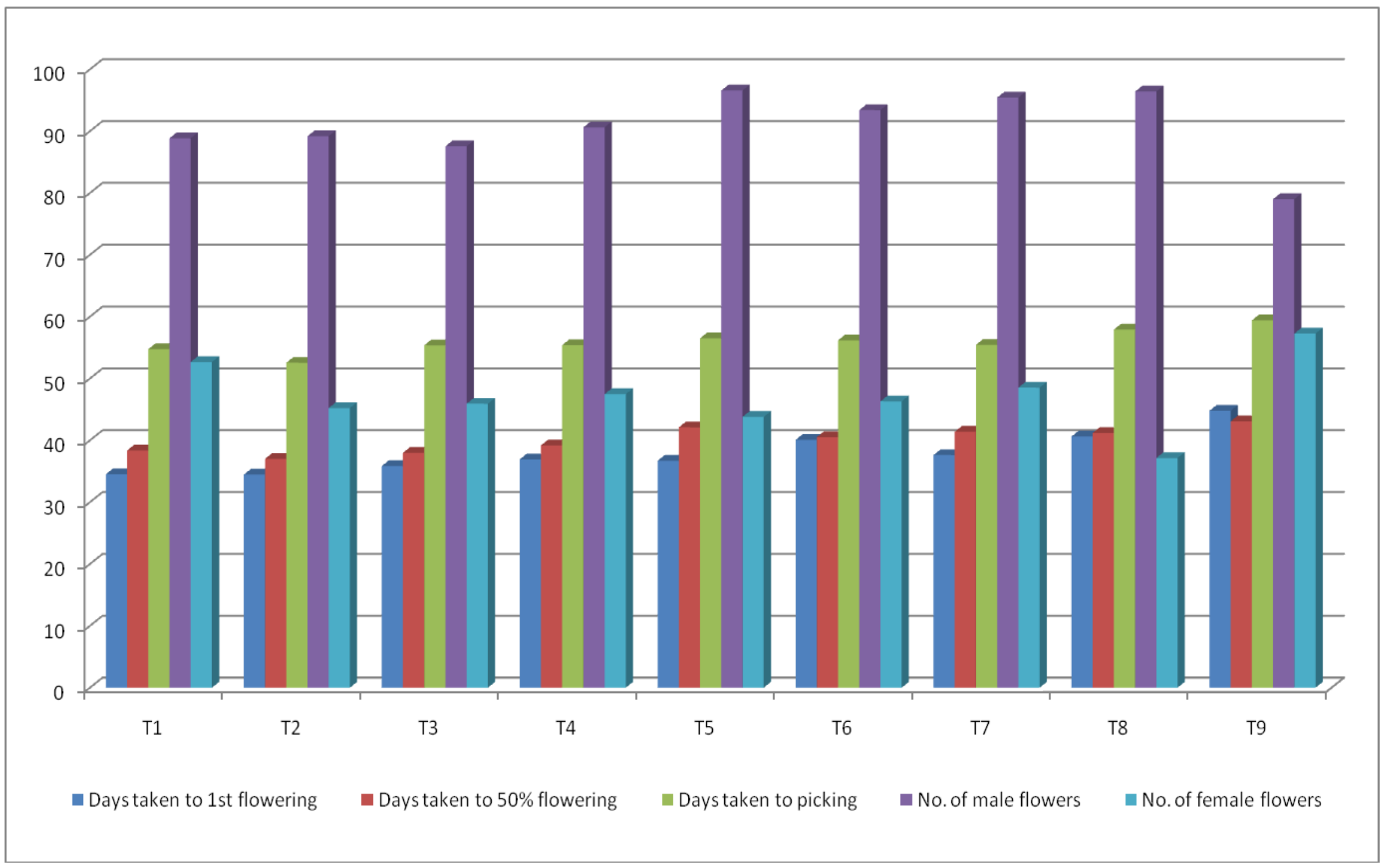


Fig.3 Fruit set percentage, fruit retention percentage, length of fruits, daimeter of fruits, number of fruits per plant and fruit yield ( $q /$ ha) of different treatments of cucumber under polyhouse condition

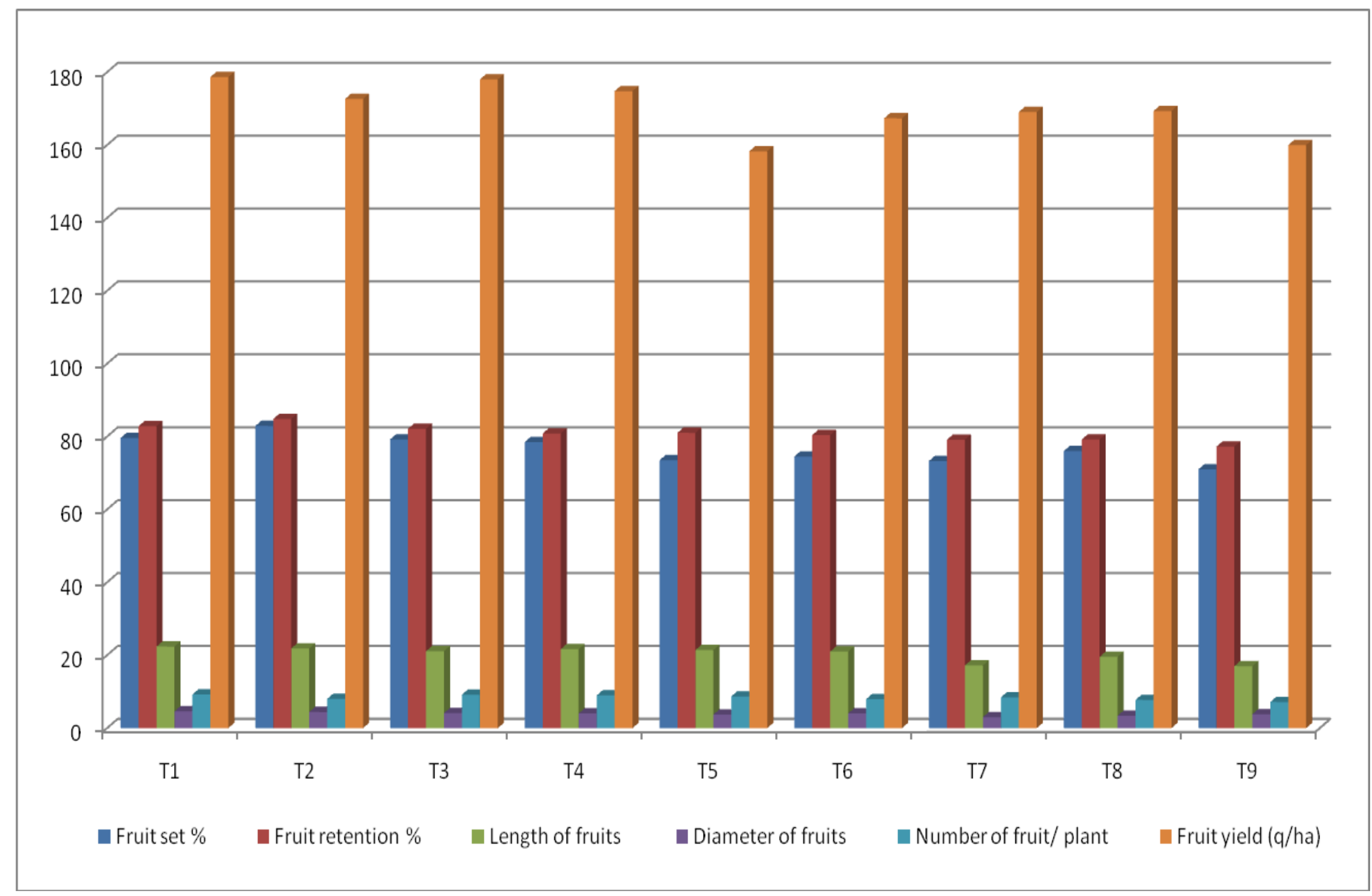


Fig.4 Cost : Benefit ratio different cucumber treatments

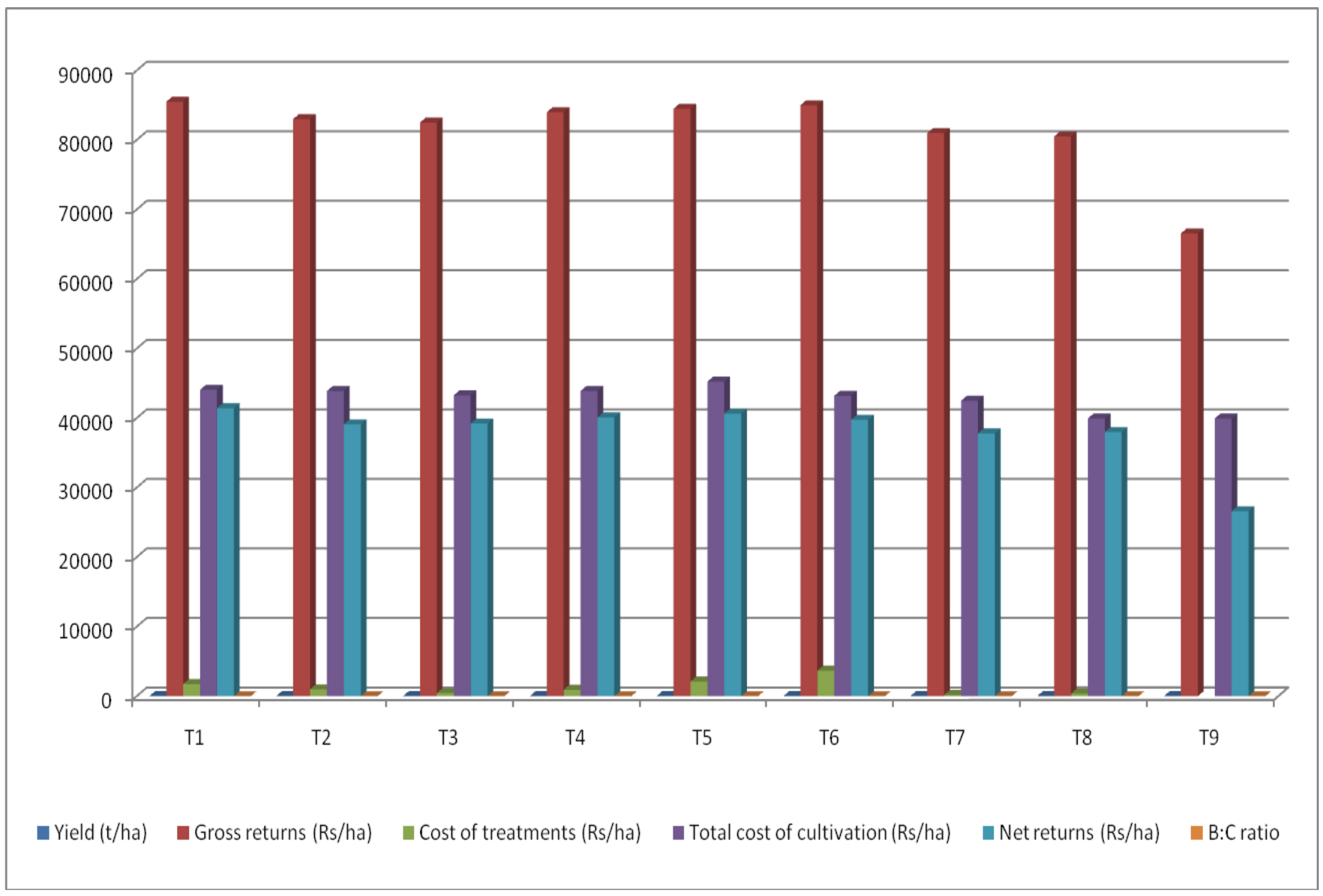


In addition, crop yield depends not only on accumulation of photosynthates during crop growth and development, but also on its partitioning to desired storage organs. These in turn, are influenced by efficiency of the metabolic processes within a plant.

An increase in fruit yield in treated plants may further be attributed to the reason that plants remain physiologically 'more active to build up sufficient assimilates for the developing flowers and fruits, ultimately leading to higher yield.

The increase in fruit yield by GA3 is probably due to an increase in carbohydrate metabolism and accumulation of carbohydrates (Mishra et al., 1972), auxin directed mobilization of metubolites from source to sink (Vasantkumar and Sreekumar, 1981).

\section{Quality parameters}

It is clear from the Table 4 that the maximum total soluble solids was recorded in the treatment $\mathrm{T}_{2}-\mathrm{GA}_{3} @ 200$ ppm (valued 6.06) while minimum was recorded in the treatment $\mathrm{T}_{7}$ - Ethrel (valued 2.16). This might be due to higher level of endogenous IAA at fruiting stage.

Treatments $\mathrm{T}_{7}$ - Etherl @200ppm and $\mathrm{T}_{8^{-}}$ Etherl@300ppm exhibited smooth texture of fruit. Whereas, remaining treatments exhibited rough texture of fruit.

\section{Cost: Benefit ratio of different cucumber treatment}

Higher money value and less cost of management are desirable traits for getting higher returns. Hence, economics of the treatments was worked out data pertaining to economics of different treatments are depicted in Table 5 and Figure 5.
The present study also indicated that, among the various growth regulators the cost: benefit ratio was higher with $\mathrm{T}_{4}$-NAA @ 50 ppm valued 1:2.7 followed by $\mathrm{T}_{1}-\mathrm{GA}_{3} @ 100 \mathrm{ppm}$ valued 1:2.6 and $\mathrm{T}_{3}-\mathrm{GA}_{3} @ 250$ ppm valued $1: 2.6$

\section{References}

Al-Masoum, A.A. and A.A. Al-Masri. 1999. Effect of ethephon on flowering and yield of monoecious cucumber. Egyptian J. Horti., 26: 229-236.

Bailey, L.H. (1969). Manual of Cultivated Plants. Macmillan Company, New York: 1116.

De Candole, A. (1967). Origin of Cultivated Plants. Hafnar Publishing Co., New York: 264.

Gedam VM, Patil RB, Suryawanshi YB, Mate SN (1998) Effect of plant growth regulators and boron on flowering, fruiting and seed yield in bitter gourd (Mormordica charantia L.). Seed Res. 26(1):97-100.

Geeta, B., Navalgatti, C.M. and Chetti, M.B. (2010). Effect of plant growth regulators on morpho-physiological parameters and yield in bittergourd. Int.J.Agri.Sci. 6(2): 504-507.

Hossain, D., Karin, M.A., Pramani, M.H.R. and Rahman, A.A.S. (2006). Effect of gibberellic acid $\left(\mathrm{GA}_{3}\right)$ on flowering and fruit development of bitter gourd. Int. J. Bot, 2: 329-332.

Latimer, J.G. 1991. Growth retardants affect landscape performance of Zinnia, Impatiens and Marigold. Hort Sci 26: 557-560.

Mishra, G.M., Prasad, B. and Sinha, S.C. (1972). Effect of plant growth substances on growth, sex expression and yield of bottlegourd. Proc. Third International Symposium on Subtropical and Tropical Horticulture, Pp. 199-207. 
Ram Asrey, Singh, G. N., Shukla, H. S. and Rajbir Singh, (2001). Effect of seed soaking with Gibberellic add on growth and fruiting of muskmelon (Cucumis melo L.). Haryana J. Hort. Sci., 30 (3 \& 4): 277-278.
Sargent, J. A. (1965). The penetration of growth regulators into leaves. Ann. Rev. Pl. Physiol., 16: 1-12.

Vasanthakumar, K. and Sreekumar, Y. (1981). Effect of growth substances on yield and quality of Pisum sativum L. var. Bonneville. South Indian J. Hort., 29: 65-67.

\section{How to cite this article:}

Ajay S. Kadi, K.P. Asati, Swati Barche and Tulasigeri, R.G. 2018. Effect of Different Plant Growth Regulators on Growth, Yield and Quality Parameters in Cucumber (Cucumis sativus L.) under Polyhouse Condition. Int.J.Curr.Microbiol.App.Sci. 7(04): 3339-3352. doi: https://doi.org/10.20546/ijcmas.2018.704.378 